Migration Studies - Review of Polish Diaspora nr 1 (171)/2019, http://www.ejournals.eu/Studia-Migracyjne/ DOI: $10.4467 / 25444972$ SMPP.19.010.10260

\title{
Adaptacyjne problemy dzieci repatriantów na tle relacji rówieśniczych
}

\author{
JOANNA KSIAZŻEK ${ }^{1}$ \\ Uniwersytet im. Mikołaja Kopernika w Toruniu
}

Z przeprowadzonych przeze mnie badań wynika, że zdecydowana większość repatrianckich dzieci w okresie nauki szkolnej jest piętnowana z powodu wychowania w kręgu języka i kultury rosyjskiej. Obawa przed odrzuceniem przez rówieśników prowadzi często do ukrywania swej kulturowej odmienności. W artykule najszerzej opisano jeden ze skutków nieporozumień na gruncie relacji rówieśniczych, czyli porzucenie przez repatrianckie dzieci języka rosyjskiego, który jest integralną częścią ich kulturowej tożsamości oraz narzędziem umożliwiającym im komunikowanie się z liczną zazwyczaj rodziną przebywającą poza Polską. Wyparcie się go, wskutek oddziaływania presji asymilacyjnej, może także wywierać niekorzystny wpływ na kształtowanie się osobowości. W artykule staram się przedstawić działanie zarysowanego mechanizmu, uwzględniając niektóre aspekty specyfiki rozwoju dziecka w wieku szkolnym, a także udział w opisywanym procesie osób dorosłych. Rozpatrując ten proces na tle możliwych wariantów procesów akulturacyjnych, postuluję konieczność podjęcia działań umożliwiających swobodną integrację badanej grupy w społeczeństwie przyjmującym, nie zaś (lub nie jedynie) jej asymilację.

Słowa kluczowe: repatrianci, asymilacja, integracja, dzieci, dwujęzyczność, dyskryminacja, edukacja międzykulturowa, stereotypy

\section{Adaptive problems of children of repatriates - a context of peer relations}

My research shows that the vast majority of repatriate children suffers from stigmatization within formal schooling in Poland. These experiences are due to the differences related to being brought up in the Russian linguistic and cultural setting. Children often attempt to conceal their cultural identity because they fear rejection. One of the main consequences of conflicts with peers is that the repatriated children abandon Russian language, despite the fact that it is an integral part of their cultural identity and a tool enabling them to communicate with the usually large family outside of

\footnotetext{
1 Adres do korespondencji: jksiazek@umk.pl
} 
Poland. A rejection of language due to assimilation-driven peer pressure may also have an adverse effect on the formation of personality. In the article, I try to present how the outlined mechanism operates by taking into account some aspects of the development specific to a school-aged child, as well investigate the role of adults in this process. As I consider this against the possible variations of the acculturation processes, I argue that action must be taken in order to enable a successful integration (rather than assimilation) into the host society for this group.

Keywords: repatriates, immigrants, children, language, bilingualism, discrimination, intercultural education, stereotypes

\section{Wstęp}

Celem tego artykułu jest ukazanie trudności adaptacyjnych dzieci repatrianckich w przestrzeni interakcji społecznych (głównie relacji rówieśniczych), a także próba przedstawienia ich przyczyn i skutków.

O Polakach przybywających do Polski w ramach repatriacji powstał szereg prac, jednak temat repatrianckich dzieci, zwłaszcza rozpatrywany pod kątem kulturowej i społecznej adaptacji w nowym środowisku, nie został dotąd kompleksowo opracowany. W artykułach i publikacjach książkowych poświęconych współczesnym repatriantom w kontekście psychologicznym (Gorbaniuk 1998, 2008), antropologicznym (Kość 2011, Kość-Ryżko 2011), socjologicznym (Hut 2002) i interdyscyplinarnym (Kość-Ryżko 2014, Sałacińska-Rewiakin 2014, Kudela-Świątek 2009) dzieci i młodzież stanowią wprawdzie zawsze uwzględnianą część społeczności repatriantów, niekiedy stają się obiektem analizy jako grupa wyodrębniona w celach badawczych według kryterium wieku, lecz nigdy nie są traktowane jako samodzielny przedmiot i podmiot badań.

W niniejszym artykule postaram się częściowo wypełnić tę lukę, choć jego bazą również nie są badania zaplanowane i skierowane specjalnie na najmłodszych repatriantów. Powstał on na marginesie badań zorientowanych na uchwycenie specyfiki społeczno-kulturowej tożsamości osiadłych w Polsce kazachstańskich Polaków². Obejmuje aspekty kulturowej adaptacji repatrianckich dzieci w ograniczeniu do ich środowiska rówieśniczego i stanowić może przyczynek do badań dalszych i w szerszym zakresie.

Badania terenowe w środowisku polskich repatriantów z Kazachstanu, na których opieram się w niniejszym artykule, były prowadzone z perspektywy antropologicznej, uwzględniającej przede wszystkim poziom doświadczeń i odczuć repatriantów. Ich analiza dotyczyła przeżyć i ocen indywidualnych i koncentrowała się na uchwyceniu

2 Badania realizowano na potrzeby pracy doktorskiej. Wywiady przeprowadzono w latach 2011-2012, w formie indywidualnej i zbiorowej, objęły one 60 repatriantów przybyłych do Polski, głównie w latach 2001-2010, oraz także wcześniej i później. Towarzyszyła im obserwacja uczestnicząca, która najlepsze efekty przyniosła podczas tygodniowego kursu adaptacyjno-językowego zorganizowanego przez ORPEG w 2012 r. w Nałęczowie. Wyniki badań, dotyczących tożsamości repatriantów, zostały opisane w mojej książce pt. "Stamtąd - tu. Obrazy tożsamości kazachstańskich Polaków w kontekście repatriacji”, która ukazała się w 2018 r. nakładem Wydawnictwa Naukowego UMK w Toruniu. Niektóre z cytatów zawartych w niniejszym artykule wykorzystano także w książce. 


\section{SM̂PP}

charakteru relacji między miejscowymi Polakami a repatriantami oraz ich znaczenia w procesie rekonstrukcji społeczno-kulturowej tożsamości repatriantów. Materiał badawczy uzyskano korzystając z metody wywiadów swobodnych, ukierunkowanych (Konecki 2000), w których repatrianci wypowiadali się na temat życia w Kazachstanie, procesu repatriacji, problemów związanych z emigracją i egzystencją w nowym środowisku oraz próbowali zdefiniować swoją przynależność narodową, etniczną, kulturową. Jeden z obszarów pytań, które zawsze poruszałam z osobami badanymi, dotyczył relacji społecznych dzieci i ewentualnych trudności adaptacyjnych w środowisku szkolnym i rówieśniczym.

Wstępna analiza uzyskanych w ten sposób narracji bardzo jasno ukazała, że proces społecznej adaptacji młodszych repatriantów, przede wszystkim zaś tych, którzy przyjechali do Polski w wieku szkolnym, a więc podlegających procesowi enkulturacji jeszcze w Kazachstanie, wiąże się z szeregiem problemów.

Wizję problemów dziecięcych uchwycono i ukazano w tekście za pośrednictwem osób dorosłych - moimi rozmówcami były najczęściej matki małoletnich dzieci, dziadkowie, dalsza rodzina, a także starsze rodzeństwo. Ich wypowiedzi nie są jedynie komentarzem i interpretacją relacjonowanych zdarzeń, dość często bowiem przywołują słowa samych dzieci.

\section{Tło kulturowe}

Potomkowie Polaków deportowanych w 1936 roku z terenów Ukrainy sowieckiej byłych terenów I RP - przybywają do Polski na mocy ustawy o repatriacji z 2000 roku i wraz z przekroczeniem granicy RP stają się jej obywatelami. Ich przodkowie, a także oni sami przez lata przymusowej emigracji próbowali zachować swą etniczną i narodową odrębność. Momentami skrajnie trudne warunki pielęgnowania rodzimej tradycji, religii i języka (ograniczenia związane ze statusem specjalnego osiedleńca, zakaz praktyk religijnych, brak możliwości nauki języka polskiego, obawa przed represjami na tle etnicznym), a także wielopokoleniowa izolacja od Polski i Polaków oraz zawieranie małżeństw mieszanych sprawiły, że zakres i forma zachowanej kultury polskiej nie spełnia dziś wielu tzw. obiektywnych kryteriów przynależności do narodu polskiego (por. Wyszyński 2000: 199-202). Jednak dzięki świadomości polskich korzeni, wierze katolickiej i zachowanym głównie dzięki niej elementom języka polskiego ${ }^{3}$, a także dzięki silnej więzi z Polską jako krajem przodków i historyczną ojczyzną, znaczna część tych osób deklaruje swą przynależność do narodu polskiego.

Próbując określić kulturową tożsamość kazachstańskich Polaków, można powiedzieć, że składają się na nią zarówno elementy kultury polskiej (więź ideologiczna,

${ }^{3}$ Językiem mówionym polskiej ludności z terenów Ukrainy był rodzaj polsko-ukraińskiego dialektu, natomiast język polski przetrwał wśród deportowanej społeczności głównie za sprawą i w formie polskich modlitw, pieśni oraz elementów liturgii kościelnej (por. Kozłowski 2005: 61, Szynkiewicz 1996: 240). 
świadomość korzeni, poczucie przynależności narodowej), rosyjskiej (przede wszystkim język, lecz także elementy charakterystycznej dla tego obszaru kultury radzieckiej), jak i kazachstańskiej (więź terytorialna, przywiązanie do dotychczasowego miejsca życia, urodzenia oraz pochówku najbliższych), co w większości przypadków nie koliduje z ich identyfikacją narodową i poczuciem bycia Polakiem.

Dla dzisiejszych repatriantów kultura polska i język polski są zarówno własne, jak i obce - w wymiarze ideowym i emocjonalnym ich rodzima kultura jest polska, jednak w wymiarze praktycznym - już nie. Po przybyciu do Polski okazuje się ona - często wbrew oczekiwaniom - w takim samym stopniu nowa i nieznana, jak dla większości imigrantów. Repatrianci muszą więc nauczyć się współczesnej formy „polskości”, na czele z językiem oraz całym uniwersum kodów kulturowych, czyli zachowań, obyczajów i norm społecznych, za pomocą których porozumiewają się współcześni Polacy (por. Hut 2002: 13-14). Przebywanie od urodzenia w kręgu kultury rosyjskiej i radzieckiej, bardzo często także silne przywiązanie do niej, sprawia, iż osoby te spotykają się często z krytyką ich autoidentyfikacji jako Polaków, jak również z przypisywaniem im narodowości rosyjskiej lub nieokreślonej „wschodniej”.

\section{Adaptacja - integracja - asymilacja}

Adaptacja do nowego środowiska, z którym stykają się repatrianci, ma wiele wymiarów. W tekście skupię się na jej kulturowym aspekcie, rozumianym jako przystosowanie się jednostki w zakresie koniecznym i wystarczającym do stworzenia płaszczyzny porozumienia i współpracy z inną kulturą i jej reprezentantami.

Adaptacja kulturowa w antropologii nazywana jest akulturacją. Dwoma jej wymiarami i zarazem pojęciami pomocnymi w definiowaniu procesów i zjawisk związanych z przystosowaniem się dzieci repatriantów do nowych warunków, które stanowić będą jednocześnie oś moich rozważań, będą pojęcia integracji i asymilacji. Z każdym z nich związane są zasadniczo odmienne założenia, a częściowo także idee i cele.

Rozpatrując te pojęcia z perspektywy teoretyczno-badawczej, w ujęciu psychologiczno-antropologicznym najbardziej odpowiednią dla poniższych rozważań wydaje się definicja integracji zastosowana przez Aleksandrę Grzymałę-Kazłowską, nawiązująca do klasycznego modelu strategii akulturacyjnych Johna Berry'ego. Według niej „integracja zakłada w mniejszym lub większym stopniu zachowywanie przez migrantów włączających się w społeczeństwo przyjmujące swej kulturowej tożsamości, (a więc odmienności)" (Grzymała-Kazłowska 2008: 35-36).

Zgodnie z koncepcją integracji Berry'ego imigranci - odpowiadając sobie na pytanie czy i w jakim stopniu przyjąć kulturę dominującą w nowym środowisku oraz

${ }^{4}$ K. Kwaśniewski, hasło „Adaptacja kulturowa”, Stownik etnologiczny: terminy ogólne, red. Z. Staszczak, PWN 1987, s. 14. 


\section{SM̂PP}

czy i w jakim stopniu zachować kulturę, w której wyrośli - uznają, iż ważne jest dla nich zarówno zachowanie własnej tożsamości kulturowej jak i utrzymanie kontaktów z członkami grupy dominującej (Berry 1997: 9-10). Pod kątem przyszłych rozważań, warto zauważyć, że zgodnie z przyjętą koncepcją stopień zachowania obu kultur jest potencjalnie zróżnicowany i określają go sami migranci. Kolejną ważną rzeczą w niniejszym rozumieniu integracji jest jej dwustronność bądź dwukierunkowość, zakładająca zarówno aktywność w tym procesie imigrantów, jak i społeczeństwa przyjmującego (które akceptuje imigrantów i wchodzi z nimi w różnorakie relacje) (Grzymała-Kazłowska 2008: 36).

Założenie o dwukierunkowości procesu integracji nakazuje przyjrzeć się wskaźnikom integracji społecznej obejmującej nie tylko relacje społeczne imigrantów ze społeczeństwem przyjmującym, ale także stosunek społeczeństwa większościowego do grupy imigranckiej (por. Piekut 2008: 218-220). To właśnie ta druga sfera ujawniła się z całą mocą jako problematyczna w relacjach moich informatorów.

Integracja zasadniczo przeciwstawiona jest asymilacji, którą Berry określił jako odrzucenie kultury własnej na rzecz dominującej (Berry 1997: 9-10)5. Model asymilacyjny zakłada niewyróżnianie się ze społeczeństwa przyjmującego (Grzymała-Kazłowska 2008: 36), określane również „wtapianiem się” w nie (por. Biernath 2008: 199). Dookreślając proces asymilacji trzeba dodać, że w odróżnieniu od integracji ma on charakter jednokierunkowy, gdyż społeczeństwo przyjmujące nie jest jego aktywną stroną. Dążąc do włączenia jednostki lub grupy do głównego nurtu życia społeczeństwa dominującego przez pozbawienie ich cech odrębności kulturowej, prowadzi do zmiany tożsamości (Posern-Zieliński 1999: 62-63).

Sferę społecznych relacji dzieci repatriantów analizuję pod kątem obydwu procesów z punktu widzenia społecznych oczekiwań, obieranych strategii oraz oszacowania warunków i szans na ich realizację.

Rozpatrując proces integracji od strony ideologiczno-normatywnej, preferuję stanowisko, zgodnie z którym „kulturowe, strukturalne i funkcjonalne zintegrowanie jest postrzegane jako pożądany stan systemu społecznego" (Grzymała-Kazłowska 2008: 30). Autor modelu strategii akulturacyjnych, drogę integracji uznał za najbardziej korzystną dla procesu adaptacji w nowym środowisku, gdyż przyczynia się ona się do zdrowego funkcjonowania psychicznego u osób przechodzących proces akulturacji (Berry 1997: 24). Podążając za nim, a także kierując się spostrzeżeniami z badań własnych, przedkładam społeczne i jednostkowe skutki procesów i postaw związanych z integracją w społeczeństwie nad procesy i ich skutki związane z asymilowaniem się migrantów z tym społeczeństwem. W odniesieniu do repatriantów (na przykładzie ich nieletnich dzieci) postaram się wykazać, że korzystne jest dla nich funkcjonowanie w modelu integracyjnym, pozwalającym na zachowanie elementów

5 Berry wyróżnił jeszcze dwie inne strategie akulturacyjne - separację (odrzucenie kultury dominującej na rzecz własnej) i marginalizację (odrzucenie obydwu kultur) (Berry 1997: 9-10). 
ich nie-polskiej kultury, przyswojonych w kraju pochodzenia, mimo iż są one formalnie osobami narodowości polskiej, a ich rodziny od zawsze były związane z kulturą polską.

Zastrzec trzeba, że przywołane pojęcia bynajmniej nie stanowią idealnych narzędzi badawczych służących do opisu procesów związanych z adaptacją repatriantów. Powstały one na bazie modelowej sytuacji zetknięcia się dwóch obcych wobec siebie kultur, podczas gdy rozdziału tego w odniesieniu do środowiska repatriantów nie można jednoznacznie przeprowadzić. Jako bazujące na rozdziale na kulturę obcą (zastaną) i swoją (rodzimą), są one znacznie lepiej przystosowane do opisu rzeczywistości imigrantów - cudzoziemców ${ }^{6}$, bo też powstały na ten właśnie użytek. Patrząc na „polskość” repatriantów bezrefleksyjnie, można dojść do wniosku, że zajmowanie się procesami asymilacji czy integracji w przypadku tej grupy jest nieuzasadnione. Jednak gdy spojrzymy na nią z perspektywy ich kulturowego bagażu, stanowiącego konglomerat elementów kultury polskiej i rosyjskiej/radzieckiej, zagubienia w nowym kraju, trudności językowych, różnic kulturowych, a także postaw społecznych wobec nich podkreślających ich odmienność, to zauważymy, że cechy te zbliżają ich do sytuacji imigrantów-cudzoziemców. W związku z tym powyższe koncepcje można z powodzeniem wykorzystać do analizy sytuacji repatriantów, a tym bardziej dzieci, które ze względu na rozwojowe ograniczenia absorpcji treści abstrakcyjnych w znikomym stopniu dysponują elementem ideologicznym, osadzającym je w kulturze polskiej jako rodzimej.

\section{Samotność w grupie}

Z rozmów z repatriantami wynika, że ich dzieci wraz z rozpoczęciem nauki w nowej szkole napotykają na problemy typowe dla imigrantów. Związane są one z porozumiewaniem się w nowym języku, wyrównywaniem różnic programowych, kwalifikowaniem do odpowiedniej klasy , bądź nadrabianiem materiału wolniej przyswajanego wskutek braków językowych. W rozwiązywaniu tych problemów pomagają programowo oferowane dodatkowe lekcje polskiego oraz lekcje z innych przedmiotów służące realizacji materiału szkolnego. Trudności te stosunkowo prędko mijają i choć ich

6 Repatrianci także są imigrantami, jednak wraz z przekroczeniem granicy Polski automatycznie stają się jej obywatelami, dla odróżnienia, tam gdzie to konieczne stosuję określanie imigranci - cudzoziemcy.

7 Problemem jest nieprzygotowanie psychologów i pedagogów kwalifikujących dzieci na odpowiedni stopień nauki szkolnej. Jedna z matek opowiadała, że w tłumaczeniu rozmowy kwalifikującej jej syna do szkoły brał udział kuzyn pani psycholog posługujący się językiem ukraińskim, co naturalnie wywołało nieporozumienia językowe i skutkowało zakwalifikowaniem chłopca w wieku szkolnym do przedszkola. Błąd został jednak szybko zauważony. Taka niefrasobliwość i ignorancja, polegająca na nieróżnicowaniu narodów i języków na wschód od polskiej granicy, jest - wynika to z moich badań - typowa w codziennych kontaktach repatriantów z miejscowymi Polakami, zaskakuje jednak w przypadku osoby psychologa. Na problem nieprzygotowania w zakresie diagnozowania dzieci wielojęzycznych i z innych kręgów kulturowych wskazuje m.in. zespół autorów publikacji Wybrane zagadnienia diagnozy psychologicznej dzieci i młodzieży w kontekście wielokulturowości oraz wielojęzyczności (Barzykowski i in. (red.): 2013: 17,20). 
pokonanie wymaga wysiłku i dużych nakładów pracy, to równocześnie ich przezwyciężenie jest dla dziecka osiągalne, może ono osiągać wymierne efekty i śledzić własne postępy, co daje mu poczucie kontrolowania sytuacji.

Nie można tego powiedzieć o trudnościach w relacjach rówieśniczych, które są głównym tematem tego artykułu. Praktycznie wszystkie badane przeze mnie rodziny z dziećmi, wskazywały na mniejsze lub większe problemy podopiecznych z funkcjonowaniem w grupie, związane z przejawami braku akceptacji wśród rówieśników. Oto jedna z typowych wypowiedzi:

Na syna mówili. Kazachem i "ruskim” i wszystkim. Przychodzit do mnie i płakał. On bał się nawet do mnie to powiedzieć, potem w rozmowie wyszło. Podtrzymał go bardzo dobry kolega, który mówit - niech sobie gadają jedna z drugą. (...) Córka to już inny problem - ona już czysto bez akcentu mówi i ja tak słucham jak ona mówi i uczę się od niej (w9; matka, syn 12 I., córka 9 I., od 4 lat w Polsce).

Zgodnie z powyższą relacją podstawą do stosowania słownej agresji wobec chłopca są kraj pochodzenia - Kazachstan oraz język rosyjski bądź wschodni akcent. Sytuują go one w przestrzeni funkcjonującego w potocznej opinii, tyleż nieprecyzyjnego, co symbolicznego określenia tego, co „ruskie”8. Brak obcego akcentu diametralnie zmienia sytuację córki - ponieważ mówi ona "czysto" i "bez akcentu” problem ten już jej nie dotyczy. Wypowiedź matki chłopca ukazuje także jego problemy z wyjawieniem i wyartykułowaniem w domu swoich szkolnych niepowodzeń oraz niekontrolowany upust emocji, które jednak nie od razu naprowadziły matkę na właściwy trop. Być może chciał on zaoszczędzić rodzicom zmartwień lub uchronić ich przed zranieniem, ponieważ przytoczone określenia pod jego adresem, mogłyby dotknąć także ich samych. Z przytoczonego fragmentu wywiadu wynika jednak, że nie wszyscy odwracają się od niego - chłopiec ma najlepszego kolegę, który wspiera go w trudnych sytuacjach.

Wypowiedzi o podobnym wydźwięku zanotowałam wiele. Inna repatriantka, mama 9-latka sygnalizuje, że podobne przejawy odrzucenia obecne są nie tylko w szkole, ale i w pozaszkolnym środowisku rówieśniczym: Na podwórku są problemy - "A, jesteś z Kazachstanu - jesteś głupi". Kilka osób tak (w1b; matka, syn 6 I., od 4 mies. w Polsce).

${ }^{8}$ Ewa Nowicka, badająca uchodźców czeczeńskich, odnotowuje, że zadomowione w słowniku potocznym słowo „Ruski” oznacza "każdego dowolnego mieszkańca byłego ZSRR. Do kategorii „Ruski” należą równie dobrze Ormianie, Białorusini, Ukraińcy, Litwini, a nawet Polacy z Litwy czy Ukrainy, jak etniczni Rosjanie". Nowicka, Postawy młodzieży wobec cudzoziemców, w: (Grzymała-Moszczyńska, Nowicka 1998: 83). Zauważa także, że stosowanie tego określenia przyczynia się do anonimowości uchodźców, ta zaś budzi niechęć do „obcych". Jej aspektem jest brak wiedzy Polaków o innych krajach: „Wszystkie kraje za wschodnią granicą Polski są w potocznym rozumieniu zamieszkiwane przez "Ruskich”, którzy są gorsi od Polaków, skłonni do ciemnych nielegalnych interesów, grożą zawleczeniem do Polski różnych form zła, przestępczości i chorób" (tamże s. 181). 
Podobnie jak w pierwszej, również i w tej wypowiedzi pretekstem do podkreślenia odmienności dziecka wobec grupy staje się fakt pochodzenia z Kazachstanu. Zachowanie rówieśników wyraźnie daje mu odczuć, że kraj, z którego przybył kojarzony jest z czymś gorszym, może więc wywołać w nim uczucie upokorzenia i wykluczenia. Określenia „Kazach” lub „ruski” stosowane wobec ucznia o sprecyzowanej, polskiej identyfikacji narodowej mogą być przez niego odczytane jako próby nieuprawnionego przyporządkowania go do grupy, z którą się nie identyfikuje i odczuwane jako krzywdzące.

Wypowiedź innej matki, Rosjanki, małżonki repatrianta, ukazuje moment, w którym odmienność jej syna zostaje zauważona, a związane z nią emocje obecne po obu stronach są eskalowane:

Od początku było w porządku, pierwsza klasa, druga, trzecia, póki nie zaczęli rozumieć. Potem on był rusek je...ny, tam różne. Musiały coś usłyszeć, od rodziców na pewno. On czwartą klasę płakat, piątą, szóstą już się bił. Akcentu już nie było, po prostu, że był "rusek". Ja jemu zawsze mówiłam: "rusek to dobrze”. - "Nie, tutaj nie jest dobrze” - on mówit. Więc było parę lat, że płakaliśmy. On pytał, że myślał, że my przyjechaliśmy do domu, a my przyjechaliśmy gdzie? Ale mu przeszło (w4; matka, syn 14 I., od 7 lat w Polsce).

Przytoczony fragment ukazuje jak głęboko zakorzeniona społecznie niechęć do Rosjan i innych narodów wschodnich niweczy wcześniejsze pozytywne lub neutralne doświadczenia i opinie dzieci ukształtowane w sposób naturalny w codziennych relacjach z rówieśnikiem - repatriantem. Początkowo dzieci nie dostrzegają inności swojego kolegi lub nie stanowi ona dla nich żadnej przesłanki, dla której miałby on być traktowany inaczej, mimo że - jak można przypuszczać - w pierwszych klasach chłopiec miał zapewne większe trudności językowe. Dopiero gdy dzieci „zaczęły rozumieć" kim jest ich kolega (być może dowiedziały się o matce Rosjance), stosunek do niego uległ zmianie. Wydaje się, że reakcje dzieci na kolegę zmieniły się w momencie, w którym ich poziom rozwoju pozwolił na przyswojenie sobie zakorzenionego w naszej kulturze stereotypu.

Relacja ta ukazuje dość jasno, iż nie tyle odmienność językowa jako taka stwarza grunt dla gorszego traktowania, ale negatywny obraz osoby posługującej się tym językiem. Mimo że język wkrótce przestał mieć znaczenie, pozostała świadomość kraju pochodzenia szkolnego kolegi (tutaj także narodowości jednego z rodziców), które stało się jego „znakiem szczególnym” czy wręcz stygmatem. Jego destrukcyjny charakter i ryzyko z nim związane polega na tym, że mimo zniwelowania akcentu, zapamiętana świadomość pochodzenia czy rosyjskie nazwisko mogą stanowić przyczynę niestosownych zachowań i komentarzy względem takiej osoby. Z drugiej strony, świadomość występowania takiego ryzyka może skutkować zachowaniem podyktowanej ostrożnością, zbytniej rezerwy i dystansu wobec nowo poznanych osób, to zaś może wpływać niekorzystnie na przyszłe relacje.

Osoba badana sugeruje także, że nieprzychylny sposób traktowania odmienności 222 na tle przynależności narodowej przekazują i utrwalają w dzieciach (świadomie bądź 


\section{SM̂PP}

nieświadomie) rodzice, w czym ma niewątpliwie wiele racji. Zaistniała sytuacja doprowadziła do fizycznej agresji między uczniami, a kryzys związany z piętnowaniem i walką ze skutkami raz przypiętej łatki trwa już „parę lat”.

Należy w tym miejscu dodać, że - jak wynika z wielu relacji - rodzice uczniów repatriantów mają ograniczone możliwości zareagowania na wskazane problemy, ponieważ często wstydzą się konfrontacji z nauczycielem z uwagi na swoje niekompetencje językowe. Okazuje się także, że sygnalizowane przez rodziców problemy mogą utrzymywać się przez dłuższy czas, nawet mimo ich interwencji w szkole. Oto ciąg dalszy wypowiedzi cytowanej już powyżej matki prześladowanego dziecka:

Później [po interwencji] było już ciszej, ciszej i później od nowa się zaczyna - „nie pójdę do szkoty" - [syn] zaczyna opowiadać dlaczego - aha, to znaczy ten sam problem, więc idę znów do szkoły... (w9; matka, syn 12 I., córka 9 I., od 4 lat w Polsce).

We fragmencie tym w dość oczywisty sposób ukazany jest opór dziecka wobec szkoły i jego zniechęcenie jako skutki sytuacji powstałej na gruncie relacji rówieśniczych.

\section{Role społeczne i priorytet grupy}

Komentując problem szykanowania repatrianckich dzieci ze względu na ich kulturową odmienność należy zwrócić uwagę na kilka kwestii. Pierwsza dotyczy roli grupy rówieśniczej w rozwoju dzieci w wieku szkolnym. To właśnie w jej ramach panują naturalne warunki do rozwijania zarówno umiejętności współpracy, jak i rywalizacji (Schaffer 2009: 136). Naznaczanie, w skrajnych przypadkach wykluczanie, uważane są za naturalne elementy procesu przydzielania i przyjmowania ról (np. przywódców, popleczników, tyranów i ofiar), typowego w grupie rówieśniczej na pewnym etapie rozwoju dzieci (por. Schaffer 2009: 136-139). W warunkach rywalizacji, w okresie wyodrębniania się funkcji społecznych w grupie, dziecku, które nie spełnia pewnych norm lub po prostu wyróżnia się czymś, bardzo łatwo zarówno wyznaczyć, jak i przyjąć rolę ofiary. Fakt pochodzenia z innego kraju (tym bardziej z kraju postrzeganego jako "gorszy”) lub odmienność językowa (objawiająca się w postaci popełnianych błędów językowych, obcego akcentu, niezrozumienia idiomów i żartów językowych) zostają wykorzystane do skonstruowania słownego narzędzia, czyli odpowiedniego epitetu, za pomocą którego następuje napiętnowanie i tym samym przyporządkowanie roli ofiary w grupie. Wszelacy "inni” (a zatem i dzieci repatrianckie), stają się doskonałym materiałem na taką właśnie ofiarę (por. Brown 2006: 206).

Po drugie, okres dziecięcy i dorastania to czas kluczowy dla kształtowania się zrębów osobowości i postaw identyfikacyjnych, uzależnionych od bycia zaakceptowanym przez grupę rówieśniczą jako najważniejszą grupę odniesienia (por. Brown 2006: 64). Tak więc dla dziecka znaczenie akceptacji jego otoczenia pogłębione jest przez wyjątkową w okresie późnego dzieciństwa i dorastania wrażliwość na opinię członków 
grupy rówieśniczej - bywa ona traktowana jako wyrocznia w wielu sprawach, podczas gdy argumenty rodziców schodzą na dalszy plan. W przypadku dziecka - imigranta tendencja ta potęgowana jest chęcią zyskania akceptacji rówieśników jako "nowego", a brak owej akceptacji może być wyjątkowo bolesny.

O ile proces różnicowania członków grupy związany jest z fazą dziecięcego rozwoju i jest dla dzieci naturalny, to dobór klucza, za pomocą którego dzieci dokonują różnicowania swoich rówieśników ściśle związany jest ze sposobami i wzorami wartościowania stosowanymi przez ich otoczenie, w tym rodziców. Bywa, że typowe dla myślenia potocznego stereotypy i uprzedzenia przekazywane są dzieciom, dla których prostota, oczywistość i kategoryczność stereotypu oraz autorytet dorosłych stanowią niezbity dowód ich prawdziwości (Czykwin, Misiejuk 2002: 63). Taki stereotypowy przekaz stanowi niewątpliwie lekceważący i pogardliwy sposób wypowiadania się na temat tzw. „ruskich”, który dzieci podchwytują i wykorzystują jako gotowy schemat różnicowania. Trzeba oczywiście dodać, że znaczenie mają tu także wzory czerpane z pozarodzinnego otoczenia dzieci - od kolegów i koleżanek, a także z mediów.

Nie jest bynajmniej bez znaczenia, jaki język i akcent jest typowy dla repatriantów i ich dzieci. Stygmatyzowana przez dzieci „inność” jest innością szczególną, wspieraną silnie przez funkcjonujący w Polsce negatywny stereotyp „ruskiego”. Coroczne sondaże, obrazujące stosunek Polaków do innych narodów, niezmiennie sytuują poziom sympatii do narodu rosyjskiego na bardzo niskim poziomie ${ }^{9}$. Oddziaływanie funkcjonujących w społeczeństwie polskim wzorców na postawy dzieci ukazują także jakościowe badania Ewy Nowickiej wśród uczniów szkoły podstawowej (której uczniowie mają przeciętny kontakt z cudzoziemcami), potwierdzając raczej niechętny stosunek uczniów do przedstawicieli narodowości rosyjskiej (Nowicka 1998: 89-98).

Przypatrując się doświadczeniom repatrianckich dzieci w Polsce na tle dotychczasowych relacji w środowisku szkolnym w Kazachstanie, sugerować można, że uczestnikom tej zmiany towarzyszy spory dysonans poznawczy. Dzieci polskie w Kazachstanie, podobnie jak dzieci około stu innych narodowości zamieszkujących ten kraj, uczęszczały do szkół współtworząc klimat wielokulturowości, a odmienność kulturowa, etniczna bądź narodowa - co zgodnie podkreślali niemal wszyscy moi rozmówcy - nie była dla nikogo powodem do nietolerancji. Poczuciu ponadnarodowej wspólnoty sprzyjał zapewne fakt, że wszystkie dzieci mówiły wspólnym językiem, jednak prawdą jest także, że etniczne pochodzenie współuczniów nie było dla nikogo tajemnicą. W świetle tych okoliczności można sobie wyobrazić jak dużym szokiem musi być dla repatrianckich dzieci wykluczenie z grupy ze względu na kojarzenie z odmienną narodowością.

9 Komunikat z badań nr 21/2017, Stosunek do innych narodów, Warszawa, luty 2017. ISSN 2353-5822 . 


\section{SM̂PP}

\section{Język a więzi rodzinne}

Naturalną reakcją dzieci w sytuacjach piętnowania z powodu domniemanego pochodzenia, które zdradza ich język lub akcent, jest niechęć do publicznego używania języka rosyjskiego zarówno przez nie same, jak i przez ich rodziców. Dzieci te usiłują odciąć się od języka rodziców, prosząc, by w miejscach publicznych lub w domu podczas odwiedzin kolegów, rodzice mówili do nich wyłącznie po polsku. Czasami po prostu rezygnują z zapraszania rówieśników do domu.

Chęć ukrycia tego języka w obawie przed brakiem akceptacji i agresją ze strony rówieśników obrazują słowa cytowanej wcześniej repatriantki, matki dwójki dzieci:

Oczywiście oni muszą znać rosyjski, u nich tam w Kazachstanie mieszkają babcie, oni muszą rozmawiać. Ale syn już kompleksujetsa rozmawiać po rosyjsku. On mówi „musisz ze mną rozmawiać tylko po polsku. Po rosyjsku możemy rozmawiać jak jesteśmy w domu sami, a jak gdzieś wychodzimy, albo jak koledzy do mnie przychodzą, musisz mówić do mnie po polsku". On już wstydzi się. Dlatego ja już się boję, że w liceum znowu będą na niego mówić, że „ruski", bo to tak na niego działa, że zabrania nam mówić po rosyjsku. On szybko agresywny robi się, on boi się tego (w9; matka, syn 12 I., córka 9 I., od 4 lat w Polsce).

Używanie języka rosyjskiego w przestrzeni publicznej budzi w chłopcu lęk z uwagi na ryzyko wystąpienia nieprzyjemnych reakcji otoczenia. Wstydzi się wręcz tego języka i nie chce, żeby kojarzono z nim choćby jego rodziców. Nie odrzucając go definitywnie, ogranicza używanie go do sfery bezpiecznej - domowej. Pierwsze zdanie powyższej wypowiedzi wskazuje na najczęściej pojawiającą się w relacjach repatriantów przyczynę, dla której nauka języka rosyjskiego staje się koniecznością. Chodzi o znajomość "kodu", który umożliwia kontakt z całą rodziną, znajdującą się w różnych częściach świata. Nie bez znaczenia w tym kontekście jest charakterystyczne podejście repatriantów do relacji rodzinnych. Stopień intensywności i zasięg rodzinnych kontaktów wśród kazachstańskich Polaków jest znacznie większy niż w Polsce (por. Grzymała-Moszczyńska, Grzymała-Kazłowska 2011: 43 ; Książek 2018: 87-93). Silna emocjonalna więź, a także potrzeba regularnych kontaktów i okazywanie sobie wzajemnego wsparcia w ramach dość szeroko rozumianej rodziny jest często wskazywaną przez moich rozmówców różnicą kulturową, zauważaną na tle analogicznych relacji wśród miejscowych Polaków. Można powiedzieć, że więzi rodzinne są dla kazachstańskich Polaków kwestią priorytetową i mają większe znaczenie dla funkcjonowania jednostek niż ma to miejsce w kręgu kultury zachodniej. W sytuacji rozproszenia rodziny (kazachstańscy Polacy często migrują do Rosji, Niemiec, mają rodziny na Ukrainie, część zostaje w Kazachstanie) jedynym sposobem, by nie stracić z nią kontaktu, jest zachowanie języka rosyjskiego, pełniącego funkcję języka łączącego rodzinę bez względu na jej miejsce zamieszkania. Repatrianci postrzegają posługiwanie się językiem rosyjskim także jako cenną umiejętność i swoisty kapitał na przyszłość, których zdobycie, dzięki wsparciu rosyjskojęzycznej rodziny, wymaga relatywnie mało wysiłku. 
Opisane rodzaje motywacji dobrze ilustruje dialog starszego małżeństwa - rodziców i dziadków:

- Wnuki nie stracity rosyjskiego, cały czas my z dziećmi rozmawiamy na rosyjski. Jak tylko wnuki przychodzą to staramy się z nimi rozmawiać po rosyjsku. Musi być jakiś wspólny język, właśnie żeby utrzymać kontakt z rodziną. Dziadkowie w Kazachstanie, rodzina w Niemczech, w Rosji, na Ukrainie. W razie chcą pojechać tam albo tutaj i co? Nie będzie jak kontaktować. Już u brata w Niemczech, córka szybko opanowała niemiecki i zaczęli w domu rozmawiać. Teraz wnuki z dziadkami nie chcą rozmawiać, bo nie mają wspólnego języka. Dziadkowie obrażeni, a zięć też taki za mądry: "pusti niemiecki język10". No a dziadek, brat rodny, Polak, i jak - na starość język niemiecki uczyć? I teraz dzieci nie chcą jechać tam do Kazachstanu, bo kontaktu z dziadkami nie mają, im nie interesno.

- Poza tym zawsze przyda się więcej języków - więcej będziesz znał o czym mówią (...) i kontakty większe naprawdę. Bywa, że i wroga swojego będziesz rozumiał co mówi, a on się nie spodziewa, że znasz. Każdy język to jest bogactwo dodatkowe (...).

- Nasi znajomi, oni tylko po polsku $w$ domu rozmawiają. Teraz oni repetytora dla syna najmują, żeby po rosyjsku uczyć. A to trzeba od małego, bo potem już dziecko nie zachce (w3a i w3b; dziadkowie, wnuki w wieku szkolnym, od 14 lat w Polsce).

Dziadkowie w sugestywny sposób opisują skutki niefrasobliwego podejścia do kwestii dwujęzyczności dzieci po repatriacji do Niemiec. Okazuje się ono zgubne dla podtrzymania kontaktu i więzi z dziadkami oraz dalszą rodziną rozsianą po świecie. Doceniają także znajomość rosyjskiego jako języka obcego i słusznie oceniają go jako „bogactwo”. Opisując sytuację znajomych, którzy początkowo zlekceważyli konieczność przyswajania rosyjskiego przez dziecko, sugerują, że z uwagi na pojawiającą się wraz z wiekiem niechęć do nauki tego języka, ich obecny trud może okazać się daremny.

Rzecz jasna, wiele zależy tu od konkretnej sytuacji rodziny - w przypadku dzieci, które urodziły się w Kazachstanie, znaczenie ma fakt, w jakim wieku dziecko przyjechało do Polski, a więc jak długo przebywało w środowisku rosyjskojęzycznym nim zaczęło naukę polskiego. Starsze w momencie migracji dzieci wymagają jedynie wsparcia i pozytywnej motywacji w podtrzymywaniu znajomości języka rosyjskiego, młodsze zaś lub urodzone już w Polsce - nauki tego języka od podstaw.

\section{Polski czy rosyjski?}

Dzieci kontynuujące jednoczesną naukę dwóch języków - polskiego w systemie szkolnym i rosyjskiego w domowym, natrafiają na typowe w takiej sytuacji trudności ${ }^{11}$. Na podstawie przytoczonych poniżej słów informatorki widać, że niekiedy wymuszają one decyzję o zaprzestaniu nauki rosyjskiego:

${ }^{10}$ W wolnym tłumaczeniu z j. ros.: niech mówi po niemiecku.

11 Lingwistyczne i psychologiczne problemy osób dwujęzycznych omawia np. J. Cieszyńska (2006: 44-54). 


\section{SM̂PP}

Ja od początku go uczyłam [rosyjskiego], ale potem przestałam, bo robił potem za dużo błędów. Rozumie dobrze, mówi dobrze, czyta tylko drukowane litery. Myślę, że jak zechce, to on się nauczy (...). Niech już tam, gdzie oceny idą tego języka się uczy (w4; matka, syn 14 I., od 7 lat w Polsce).

W sytuacji konfliktu podczas nauki dwóch języków i konieczności dokonania wyboru, matka decyduje się na naukę polskiego, ponieważ od niego zależą szkolne oceny syna. Wyraża przy tym nadzieję, że zechce on kiedyś nauczyć się lepiej rosyjskiego. Przypominając przytaczane wcześniej okoliczności bijatyk, w które wdawał się chłopiec z powodu przezwisk, zasadnym jest pytanie czy i na ile dziecko zdoła rozdzielić sfery domową i szkolną i zachować pozytywny stosunek do języka, którym posługuje się jego rodzina, czy raczej wskutek negatywnej atmosfery wytworzonej wokół niego w grupie rówieśniczej, utrwali niechęć do kontaktu z tym językiem, a w konsekwencji również trudności w uczeniu się go.

Wydaje się, że sytuacje deprecjonowania „rodzinnego" języka w grupie rówieśniczej repatrianckich dzieci nie pozostają bez wpływu na postawy rodziców wobec jego nauki. Rodzicom dzieci repatrianckich bardzo zależy na tym, by ich dzieci zyskały akceptację polskich rówieśników. W obliczu niepewności co do własnej tożsamości kulturowej (zob. np. Katarzyna Kość-Ryżko 2014:136, Książek 2018) rodzice wyrażają życzenie, by ich dzieci miały pod tym względem jasną sytuację, by, jak to ujmują, tę ojczyznę miały; by byli już jako Polacy i mieszkali w swojej ojczyźnie. Nie sposób jednak czuć się u siebie bez uzyskania społecznej akceptacji, która w przypadku dzieci szkolnych oznacza akceptację kolegów i koleżanek. Nie można więc wykluczyć, że rodzice świadomi niepowodzeń szkolnych z powodu tego, co łączy ich dzieci z kulturą kręgu rosyjskiego, ulegają wobec sprzeciwu lub niechęci dziecka do nauki pogardzanego przez rówieśników języka, obniżają swe wymagania i stają się mniej konsekwentni w tej dziedzinie.

\section{Ukrywanie stygmatu}

Jak widać naturalną konsekwencją sytuacji, gdy język jest czynnikiem pośrednim w procesie stygmatyzacji, jest strategia unikania go oraz perfekcyjne opanowanie języka polskiego wraz z pozbyciem się wschodniego akcentu. Nie chodzi więc o doskonalenie języka jedynie w celach poprawy komunikacji, lecz także o zamaskowanie związków budzących skojarzenie ze wspomnianym stereotypem poprzez maksymalne wtopienie się w społeczne łło. Tego typu zachowania można bez wątpienia zaliczyć do postaw asymilacyjnych. Zależność tę potwierdza fakt, że dla repatriantów synonimem udanej adaptacji w społeczeństwie jest najwyższy stopień posiadanych kompetencji w zakresie języka polskiego, o czym świadczą przykładowe wypowiedzi: Najlepiej zaadaptowała się najmłodsza siostra - mówi płynnie, bez akcentu. Repatriantka zapytana, czy jej wnuki mają w szkole trudniej od dzieci miejscowych, odpowiada: wydaje 
się, że nie, jak gadają, to ich nie odróżnisz od Polaków. Cytaty te potwierdzają tezę, że mówienie bez akcentu jest pożądane, ponieważ pozwala uniknąć odróżniania się.

Sytuacja unikania posługiwania się językiem rosyjskim w przestrzeni publicznej w związku z ryzykiem negatywnych reakcji społeczeństwa stanowi przykład ukrywania stygmatu, którym dzieci repatrianckie zostają naznaczone w środowisku szkolnym. Marzena Rusaczyk odwołując się do goffmanowskiej teorii piętna (Goffman 2005) uznaje, iż najczęstszym sposobem radzenia sobie z sytuacją stygmatyzowania odmienności, z którą mają do czynienia imigranci, jest strategia ukrywania go. „W przypadku możliwości ukrycia negatywnie stereotypizowanej odmienności - pisze autorka - osoba może w swoisty sposób manipulować percepcją innych aktorów, sama decyduje komu, kiedy i gdzie wyjawi swoje niekiedy wstydliwe tajemnice. Ukrywanie stygmatu pozwala na w miarę bezbolesne poruszanie się w rzeczywistości „normalsów” i oferuje osobie psychologiczne zabezpieczenie przez antycypowanym przez siebie ryzykiem bycia piętnowaną" (Rusaczyk 2009: 314). Strategia ta, częsta zwłaszcza, gdy egzystencja jednostki w nowym środowisku jest silnie uzależniona od wchodzenia w interakcje z przedstawicielami kultury goszczącej (co jest bezsprzecznie udziałem dzieci szkolnych), stanowić ma nieintencjonalny punkt wyjścia do asymilacji oraz zagrożenie dla społecznej tożsamości tych osób, poprzez pogłębianie dystansu wobec nich (tamże: 314-317) ${ }^{12}$.

Podsumowując, wydaje się, że pozytywna motywacja, związana z utrzymaniem kontaktów rodzinnych, służąca nauce języka, koliduje z presją szkolną i wywołaną nią strategią asymilacyjną, nakierowaną na pozbycie się znamion obcości i inności.

\section{Wnioski i rekomendacje}

Analiza zaprezentowanych przypadków prowadzi do podstawowego wniosku, iż brak akceptacji społecznej oraz presja wywierana przez rówieśników, z którymi spotykają się repatrianckie dzieci szkolne, prowadzi do wykształcenia u nich postaw asymilacyjnych i jednocześnie zmniejsza szanse na faktyczną integrację w przyjętym tu rozumieniu. Dążenie do postaw asymilacyjnych, zwiększone specyficznym dla tego wieku uzależnieniem jednostki od akceptacji grupy, wpływa niekorzystnie na proces zachowywania i uczenia się języka „rodzinnego”, co prowadzi do zakłócenia więzi rodzinnych. Wtórny efekt asymilacyjny polega zaś na tym, że rozluźnianie się więzi rodzinnych zbliża model kontaktów rodzinnych reprezentowany przez kazachstańskich Polaków do wzorca dominującego w Polsce.

${ }^{12}$ Moje badania wśród dorosłych repatriantów potwierdzają istnienie tendencji wśród części z nich do świadomego dystansowania się wobec grupy określanej jako Polacy z Kazachstanu, ze Wschodu, bądź inaczej. Jego przejawami, oprócz niechęci do używania języka rosyjskiego w sytuacjach publicznych, są chęć odseparowania się od osób sobie podobnych i unikanie kontaktów z nimi na rzecz pielęgnowania relacji z miejscowymi Polakami, por. Książek 2018: 100-102. 


\section{SM̂PP}

Wskutek stygmatyzacji i wykluczenia młode osoby ponoszą niewątpliwe koszty psychiczne, mogące oddziaływać na nie oraz ich otoczenie w przyszłości. Biorąc pod uwagę, że język w dużym stopniu kształtuje emocjonalną i poznawczą tożsamość dziecka oraz wpływa na niektóre aspekty jego osobowości (Czykwin, Misiejuk 2002: 67), możliwe są także ponoszone wraz z jego utratą bądź deprecjonowaniem kryzysy związane z rozwojem osobowości.

Odrzucenie języka pierwszej kultury pozbawia jej byłych uczestników wielu korzyści płynących z jego znajomości. Osoby te tracą pewien potencjał w wymiarze rozwoju indywidualnego (w konsekwencji także społecznego), korzystny dzięki temu, że - jak to ujęła Jadwiga Cieszyńska w swym studium poświęconym dwujęzyczności znajomość drugiego języka pozwala nam uniknąć jednostronnego oglądu świata i nie utknąć W ciasnej siatce pojęć jednego systemu opisywania rzeczywistości (Cieszyńska 2006: 45). Znika też możliwość wykorzystania umiejętności językowych i wielokulturowych kompetencji w tworzeniu ponadnarodowych sieci społecznych ${ }^{13}$ służących dwustronnym polsko-kazachstańskim kontaktom ekonomicznym, dyplomatycznym i kulturowym, znaczącym także w kontekście pełnienia ról społecznych ambasadorów obu państw w celu ożywienia i zacieśnienia biznesowych i kulturalnych kontaktów z Polakami, którzy pozostali w Kazachstanie.

W potocznym mniemaniu, polska narodowość i polskie korzenie niejako predestynują repatriantów do przyjęcia postawy asymilacyjnej, polegającej na wyzbyciu się tego co nie-polskie. Postawy asymilacyjnej oczekuje od nich większość społeczeństwa (por. Grzymała-Moszczyńska, Grzymała-Kazłowska 2011: 38). Asymilację uznaje się także za bezsprzeczną w wymiarze kolejnych pokoleń. Podczas gdy w przypadku osób dorosłych, ich dojrzalsza, a więc i silniejsza konstrukcja psychiczna, rozmaite warianty kontaktów w pracy uwarunkowane jej charakterem oraz możliwość aktywnego wpływania na relacje społeczne, powodują, że są oni w stanie przeciwstawić się presji asymilacyjnej i uchronić swoją odmienność, dzieci mają bardzo ograniczone możliwości w tym zakresie, wymagają więc aktywnego wsparcia rodziców, którzy nie musieliby wybierać, czy społecznie opłaca się wspierać naukę języka rosyjskiego. Do oczekiwań asymilacyjnych przyczynia się dominujący w przestrzeni oficjalnej, mocno uproszczony obraz repatrianta, pomijający jego kulturową odmienność, kolidujący mocno z faktycznym odbiorem społecznym tej grupy, w tym - jak ukazałam - na gruncie relacji dziecięcych. Oczekiwania asymilacyjne wobec repatriantów mogą być jedną z przyczyn słabej obecności ich samych oraz ich dzieci jako grupy celowej w przestrzeni działań skierowanych na ochronę kulturowej odmienności imigrantów i oswajanie z nią społeczności "gospodarzy".

Na obecny także i w przypadku repatriantów dylemat dotyczący z jednej strony akcentowania odmienności, z drugiej jej niedostrzegania, zwraca uwagę Sławomir

${ }^{13} \mathrm{Na}$ temat znaczenia transnarodowych sieci społecznych w kontekście migracji i migrantów zob. np. Faist 2006. 
Łodziński (2008: 85). Jego zdaniem „ochrona kultury imigrantów w ramach polityki integracji rodzi sprzeczne oczekiwania, które są trudne do rozwiązania. Z jednej strony prowadzi do sytuacji, w której odrębność danej wspólnoty imigranckiej jest postrzegana jako coś wyróżniającego ze społeczeństwa, co ją dystansuje od pozostałej części społeczeństwa (jego większości), podkreślając w sferze publicznej wartość podziału na „my” i „oni”. Z drugiej - odmowa uznania tej odmienności może przyczynić się do odrzucenia ważnych potrzeb tych społeczności (szczególnie religijnych i językowych), a także utwierdzenia istniejących nierówności etnicznych i dyskryminacji w społeczeństwie".

Zasugerowany w artykule problem niewystarczających działań oswajających „inność" podejmowanych przez kadrę pedagogiczną w szkole, może być wynikiem takiego dylematu, związanego, jak się wydaje, z postrzeganiem integracji jako generującej „inność"14. Interesujące w tym kontekście są spostrzeżenia Elżbiety Czykwin, zajmującej się percepcją odmienności dzieci z białoruskiej mniejszości narodowej na tle społeczności szkolnej na Białostocczyźnie. Nauczyciele, pytani przez nią o podejście i działania wobec odmienności kulturowej (zwłaszcza wyznaniowej) części uczniów w klasie, odpowiadali, że nie podejmują żadnych kroków, bo nie chcą różnicować dzieci dla ich dobra i traktują to jako przejaw tolerancji. Zdaniem badaczki zachowania takie są przejawem „tendencji do homogenicznego widzenia rzeczywistości społecznej, będącego wyrazem źle pojętej równości, demokratyzacji i tolerancji”, przy czym "niechęć do 'zaznaczania różnic kulturowych' oznacza de facto zgodę na gwałt symboliczny i wykorzenienie kultury mniejszości" (Czykwin, Misiejuk 2002: 52). Niedostrzeganie faktu istnienia odmienności kulturowej autorka postrzega jako postawę „ekonomiczną", zwalniającą z podejmowania jakichkolwiek kroków, postawa ta jest łatwa do zaakceptowania tym bardziej, że bywa zracjonalizowana jako „tolerancyjna” i „sprawiedliwa” (Czykwin, Misiejuk 2002: 53). W efekcie dzieci białoruskiej mniejszości zdane są na dramatyczny wybór między odrzuceniem a asymilacją, bądź schizofrenią życia w dwóch odmiennych światach (Czykwin, Misiejuk 2002: 55). Wydaje się, że jeszcze większa tendencja do „nieodróżniania” może zachodzić w przypadku nauczycieli stykających się z dziećmi repatrianckimi jako dziećmi narodowości polskiej.

Reakcje dzieci polskich na zaprezentowany w niniejszym artykule rodzaj inności, wynikające zapewne z obaw przed nią i/lub stanowiące bezrefleksyjne powielanie wzorów funkcjonujących w ich najbliższym otoczeniu, dowodzą, że kwestie obchodzenia się z innością w bezpośrednim z nią kontakcie, tolerancji wobec odmienności i relacji międzykulturowych funkcjonujące w programach szkolnych w obecnym wymiarze są niewystarczające. Wątpliwe jest, by projekty i akcje organizacji pozarządowych zdołały wypełnić te luki, w związku z tym warto rozważyć wypracowanie

14 Stanowisko takie prezentują krytycy modelu integracji (np. P. Mecheril, w Prekäre Verhältnisse über natio-ethno-kulturelle (Mehrfah-) Zugehörigkeit, Münster 2003: Waxmann, za: Kindler 2008: 68. 


\section{SM̂PP}

rozwiązań systemowych włączających repatriantów w krąg osób obejmowanych działaniami zorientowanymi na te kwestie. Odpowiednio dobrane działania integracyjne pozwoliłyby być może uniknąć wytwarzania niekorzystnej presji asymilacyjnej zarówno na repatriantów, jak i innych imigrantów.

W tym miejscu zasadnym jest pytanie o najlepiej dostosowany do zarysowanego problemu charakter działań integracyjnych. Konsekwencją postrzegania integracji jako procesu dwukierunkowego byłoby opowiedzenie się za takimi działaniami integracyjnymi ( $w$ ramach polityki integracyjnej państwa lub w formie inicjatyw pozarządowych, oddolnych), które uwzględniałyby tę dwukierunkowość. Tak więc oprócz działań bezpośrednich skierowanych na imigrantów powinny być zastosowane także przeciwdziałające wykluczeniu środki pośrednie aktywizujące społeczeństwo przyjmujące ${ }^{15}$. Zatem obok kursów językowo-adaptacyjnych i dodatkowych godzin polskiego, konieczne byłyby też działania informujące i edukacyjne skierowane do szkolnej społeczności przyjmującej (na temat historii kazachstańskich Polaków i innych diaspor polskich na Wschodzie, na temat byłych republik Związku Radzieckiego sąsiadujących z Polską, a także ukazujące działania mechanizmów, które powodują zachowywanie się wobec repatriantów w sposób krzywdzący). W szerszym kontekście wpisywałyby się one w propozycje rozwiązań obejmujących imigrantów, cudzoziemców oraz wszelkich "innych" zasugerowane na podstawie wieloletnich doświadczeń i badań naukowych przez Krystynę M. Błeszyńską. Polegać miałyby między innymi na zmianach w programach kształcenia zarówno dzieci - w kierunku kształtowania (postulowanych przez J. Delorsa ${ }^{16}$ ) umiejętności „bycia wśród innych" i "współdziałania z innymi”, przy włączeniu do treści kształcenia edukacji międzykulturowej - jak i pedagogów i psychologów szkolnych w kierunku odejścia od dominacji psychologii rozwojowej w kierunku psychologii wychowawczej (Błeszyńska 2012: 539).

Na podstawie powyższych rozważań wydaje się, że celowe lub niecelowe niedostrzeganie odmienności nie jest dobrym sposobem na rozwiązanie problemów w obszarze relacji społecznych grup imigranckich. O tym, że ona istnieje świadczą między innymi wskazane $w$ tym artykule problemy dzieci repatriantów z nawiązywaniem relacji rówieśniczych. Mądrze zaplanowane działania integracyjne nie stwarzają ani nie pogłębiają odmienności, lecz - co ważne - także jej nie eliminują. Uczą natomiast przyjaznego obchodzenia się z nią. Nie tylko przykłady doświadczeń dzieci repatriantów, ale i inne, do których nawiązałam w tym artykule, wskazują na dużą potrzebę i pole do działania dla edukacji międzykulturowej w polskich szkołach.

15 Koncepcję środków pośrednich i bezpośrednich rozwinęli m.in. F. Heckmann i D. Schnapper w: The Integration of Immigrants in European Sicieties, Stuttgart 2003: Lucius\&Lucius, za: Stefańska 2008: 125.

16 J. Delors (red.), Edukacja - jest w niej ukryty skarb: raport UNESCO Międzynarodowej Komisji ds. Edukacji Dwudziestego Pierwszego Wieku pod przewodnictwem Jaques'a Delorsa, Warszawa 1998: Stowarzyszenie Oświatowców Polskich, za: Błeszyńska 2012: 539. 


\section{Bibliografia}

Barzykowski K. i in. (red.) (2013), Wybrane zagadnienia diagnozy psychologicznej dzieci i młodzieży w kontekście wielokulturowości oraz wielojęzyczności, Warszawa: Ośrodek Rozwoju Edukacji.

Berry J.W. (1997), Immigration, Acculturation, and Adaptation, "Applied Psychology: An International Review", 46 (1), 5-68; http://onlinelibrary.wiley.com/doi/10.1111/j.1464-0597.1997. tb01087.x/pdf. (dostęp 12.12.2014).

Biernath M. (2008), Różnorodność integracji - jej wymiary i mechanizmy, w: Grzymała-Kazłowska A., Łodziński S. (red.), Problemy integracji imigrantów. Koncepcje, badania, polityki, Warszawa: Wydawnictwo Uniwersytetu Warszawskiego, s.180-206.

Błeszyńska K.M. (2012), Między stereotypem a doświadczeniem drogi. dydaktyka różnicowa kształcenia dzieci migrantów, w: Szczurek-Boruta A., Ogrodzka-Mazur E. (red.), Poza paradygmaty. Pedagogika międzykulturowa, Tom 2, Księga pamiątkowa dedykowana Profesorowi Tadeuszowi Lewowickiemu, Toruń: Wyd. Adam Marszałek, s. 516-544.

Brown R. (2006), Procesy grupowe. Dynamika wewnątrzgrupowa i międzygrupowa, Gdańsk: Gdańskie Towarzystwo Psychologiczne.

CBOS Komunikat z badań nr 21/2017 Stosunek do innych narodów, Warszawa, luty 2017. ISSN 2353-5822. https://www.cbos.pl/SPISKOM.POL/2017/K_021_17.PDF (dostęp 15.12.2018).

Cieszyńska J. (2006), Dwujęzyczność i dwukulturowość - przekleństwo czy bogactwo? O poszukiwaniu tożsamości Polaków w Austrii, Kraków: Wydawnictwo Naukowe Akademii Pedagogicznej.

Czykwin E., Misiejuk D. (2002), Dwujęzyczność i dwukulturowość w perspektywie psychopedagogicznej, Białystok: Transhumana.

Faist T. (2006), The Transnational Social Spaces of Migration, Working Papers - Center on Migration, Citizenship and Development; 10, Bielefeld: COMCAD; https://www.ssoar.info/ssoar/bitstream/handle/document/35069/ssoar-2006-faist-The_transnational_social_spaces_of.pdf?sequence $=1$

Goffman E. (2005), Piętno. Rozważania o zranionej tożsamości, Gdańsk: Gdańskie Wydawnictwo Psychologiczne.

Gorbaniuk J. (1998), Problemy adaptacji młodzieży polskiego pochodzenia ze Wschodu studiującej w Polsce - na przykładzie grupy studentów z Lublina, „Przegląd Polonijny”, nr 3, s. 87-102.

Gorbaniuk J. (2008), Psychospołeczne uwarunkowania zadowolenia z repatriacji Polaków z Kazachstanu, Lublin: Wydawnictwo KUL.

Grzymała-Kazłowska A. (2008), „Integracja” - próba rekonstrukcji pojęcia, w: Grzymała-Kazłowska A., Łodziński S. (red.) (2008), Problemy integracji imigrantów. Koncepcje, badania, polityki, Warszawa: Wydawnictwo UW, s. 29-50.

Grzymała-Kazłowska A., Łodziński S. (red.) (2008), Problemy integracji imigrantów. Koncepcje, badania, polityki, Warszawa: Wydawnictwo UW.

Grzymała-Moszczyńska H., Grzymała-Kazłowska A. (2011), Repatrianci z Kazachstanu - charakterystyka i główne problemy adaptacyjne, Warszawa: Komitet Badań nad Migracjami.

Halik T., Nowicka E., Połeć W. (2006), Dziecko wietnamskie w polskiej szkole, Warszawa: Wydawnictwo ProLog.

Hut P. (2002), Warunki życia i proces adaptacji repatriantów w Polsce w latach 1992-2000, Warszawa: IPS UW. 


\section{SM̂PP}

Kindler M. (2008), Transnarodowość. Nowe teorie migracyjne a wyzwania integracji imigrantów, w: Grzymała-Kazłowska A., Łodziński S. (red.) (2008), Problemy integracji imigrantów. Koncepcje, badania, polityki, Warszawa: Wydawnictwo UW, s. 51-71.

Konecki K. (2000), Studia z metodologii badań jakościowych. Teoria ugruntowana, Warszawa: PWN.

Kość K. (2011), Adaptacja polskich repatriantów z Kazachstanu. Oblicza obcości wśród swoich, w: Rusek H., Pieńczak A. (red.), Etnologiczne i antropologiczne obrazy świata - konteksty interpretacyjne, Cieszyn: Offsetdruk i Media, Katowice: UŚ, s. 301-312.

Kość-Ryżko K. (2011), „Nic mnie serce za Kazachstanem nie boli...”, Wyzwania akulturacyjne polskich repatriantów z Kazachstanu, „Etnografia Polska” t. LV, z. 1-2, s. 149-178.

Kość-Ryżko K. (2014), Wykorzenieni. Dylematy samookreślenia polskich repatriantów z Kazachstanu. Studium etno-psychologiczne, Warszawa: Instytut Archeologii i Etnologii PAN.

Kozłowski J.B. (2005), Demograficzny, społeczno-zawodowy i kulturowy wizerunek diaspory polskiej w Kazachstanie, „Przegląd Polonijny” XXXI, z. 2, s. 31-71.

Książek J. (2018), Stamtąd - tu. Obrazy tożsamości kazachstańskich Polaków w kontekście repatriacji, Toruń: Wyd. Naukowe UMK.

Kudela-Świątek W. (2009), Swoi wśród obcych, obcy wśród swoich... Repatrianci z Kazachstanu we wspótczesnym spoteczeństwie polskim, w: „Swój” i „obcy”. Materiały z I międzynarodowej sesji humanistycznej, Toruń 17-19 V 2009, s. 203-214.

Łodziński S. (2008), Integracja kultury imigrantów. Spory wokół ochrony praw społeczności imigranckich w Europie, w: Grzymała-Kazłowska A., Łodziński S. (red.), Problemy integracji imigrantów. Koncepcje, badania, polityki, Warszawa: Wydawnictwo Uniwersytetu Warszawskiego, s. 72-92.

Nowicka E. (1998), Postawy młodzieży wobec cudzoziemców, w: Grzymała-Moszczyńska H., Nowicka E., Goście i gospodarze. Problem adaptacji kulturowej w obozach dla uchodźców oraz otaczających je społecznościach lokalnych, Kraków: Nomos, s. 75-112.

Piekut A. (2008), Wielość wymiarów - zatem jaka integracja? Przegląd tematyki i metod badań integracyjnych, w: Grzymała-Kazłowska A., Łodziński S. (red.) (2008), Problemy integracji imigrantów. Koncepcje, badania, polityki, Warszawa: Wydawnictwo Uniwersytetu Warszawskiego, s. 207-243.

Rusaczyk M. (2009), Migranci i ich sposoby radzenia sobie z sytuacją imigranta w perspektywie stygmatu społecznego. Implikacje dla problematyki kreowania wspólnoty i potrzeby edukacji międzykulturowej, w: Nikitorowicz J., Misiejuk D. (red.), Procesy migracji w społeczeństwie otwartym. Perspektywa edukacji międzykulturowej, Białystok: Transhumana, s. 307-324.

Sałacińska-Rewiakin J. (2014), Deportowani i repatrianci. Trzy pokolenia kazachstańskich Polaków wobec problemu tożsamości, Warszawa: Narodowe Centrum Kultury.

Schaffer R.H. (2009), Psychologia dziecka, Warszawa: Wydawnictwo Naukowe PWN.

Staszczak Z. (red.) (1978), Słownik etnologiczny: terminy ogólne, Warszawa-Poznań: PWN.

Stefańska R. (2008), Między multikulturalizmem a asymilacją. Polityki integracyjne w Europie, w: Grzymała-Kazłowska A., Łodziński S. (red.), Problemy integracji imigrantów. Koncepcje, badania, polityki, Warszawa: Wydawnictwo Uniwersytetu Warszawskiego, s. 123-156.

Szynkiewicz S. (1996), Polacy w Kazachstanie. Świadomość etniczna i stosunki z obcymi. „Etnografia Polska", t. XL, z. 1-2, s. 237-253.

Wyszyński R. (2000), Polscy przesiedleńcy w Kazachstanie - polskość rezydualna, w: Nowicka E. (red.) Polacy czy cudzoziemcy, Kraków: Nomos, s. 127-206. 